\title{
First report of Botrytis cinerea on Miconia cinnamomifolia
}

\author{
M. A. Silva ${ }^{1}$ - F. R. Corrêa ${ }^{1}$ D. B. Pinho ${ }^{2}$ - O. L. Pereira ${ }^{1}$ - G. Q. Furtado ${ }^{1}$
}

Received: 8 July 2016 / Accepted: 30 September 2016 /Published online: 6 October 2016

(C) Australasian Plant Pathology Society Inc. 2016

\begin{abstract}
Miconia cinnamomifolia is a forest species with occurrence in Brazilian Atlantic rainforest. Seedlings from a nursery located in Viçosa (State of Minas Gerais, Brazil) presented symptoms of damping-off. Based on morphology and the ITS sequence, the fungus was identified as belonging to the species Botrytis cinerea. This is the first record of this hostpathogen relationship in Brazil.
\end{abstract}

Keywords Hyphomycete · Forest species · Gray mold · Native tree

The species Miconia cinnamomifolia (Melastomataceae) is a forest species from Brazil that can reach $22 \mathrm{~m}$ in height and $50 \mathrm{~cm}$ in trunk diameter. This species is recommended for building due its wood to have moderated density and it has good durability in dry conditions. It also has ornamental characteristics that provide its use for afforestation of parks and gardens. Furthermore, its fruits are highly attracted to birds that do the dissemination of seeds in the area. It occurs naturally between the south and northeast of Brazil in Atlantic rainforest (Lorenzi 1992).

There are few reports of pathogens associated with this tree species in Brazil and in the world, only four species of fungi: Asterina transiens., Bagnisiopsis peribebuyensis, Dothidina,

G. Q. Furtado

gfurtado@ufv.br

1 Departamento de Fitopatologia, Universidade Federal de Viçosa, Viçosa, Minas Gerais, Brazil

2 Departamento de Fitopatologia, Universidade de Brasília, Brasília, Distrito Federal, Brazil
Phaeofabraea miconiae (Mendes and Urben 2016; Farr and Rossman 2016).

In January 2014, approximately $90 \%$ of $M$. cinnamomifolia seedlings (one-month-old) were observed with severe symptoms of damping-off in a forest nursery located in the municipality of Viçosa, Minas Gerais, Brazil. The seedlings displayed necrosis and intense gray sporulation throughout the canopy (Fig. 1).

The pathogen was directly isolated from sporulating lesions and single-spore pure culture was obtained on potato dextrose agar (PDA). The fungus was grown according to Caires et al. (2015). The isolate COAD1956 was deposited at the culture collection Coleção Octávio de Almeida Drumond in Brazil. The fungus had the following morphological features: hyphae were branched, septate, and brownish. Conidiophores were long and dark, with an apical branch and dilated conidiogenous cells. Conidia were globose to ellipsoid, septate, subhyaline, and 6 to $13 \mu \mathrm{m}$ long and 6 to $9 \mu \mathrm{m}$ wide.

These morphological characteristics are similar to Botrytis cinerea (Ellis 1971). For an accurate identification, genomic DNA of the isolate was extracted using a Wizard Genomic DNA Purification Kit. The ITS rDNA region was amplified using ITS1 and ITS4 primers (White et al. 1990). The purification and sequencing of DNA were performed by Macrogen (Seoul, South Korea).

The ITS sequence obtained (GenBank Accession No. KP967564) was $100 \%$ identical to the sequence KF859918 from B. cinerea (CBS131.28).

To evaluate the pathogenicity, six healthy, 1.5-month-old seedlings of $M$. cinnamomifolia were inoculated by spraying the foliage with a conidial suspension $\left(10^{5}\right.$ conidia $\left.\mathrm{ml}^{-1}\right)$ and six control plants were sprayed with distilled water. 
Fig. 1 Damping-off in seedlings of Miconia cinnamomifolia caused by Botrytis cinerea.

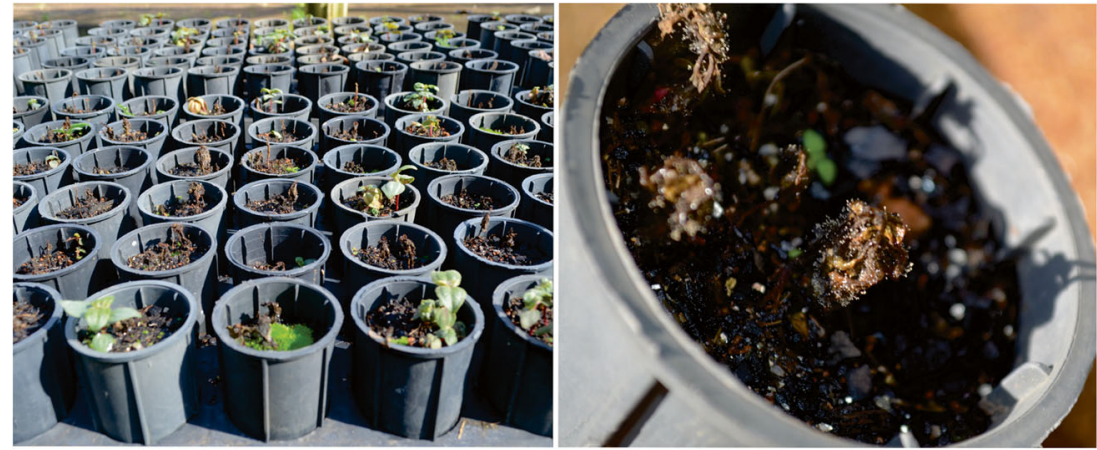

The seedlings were covered with humid plastic sacks and maintained in growth chamber at $19{ }^{\circ} \mathrm{C}$ and a 12-h light photoperiod $\left(165.3 \mu \mathrm{mol} / \mathrm{s} / \mathrm{m}^{2}\right)$. After $48 \mathrm{~h}$ the plastic sacks were removed. Symptoms were consistently similar to those initially observed in the nursery and all plants developed leaf necrosis five days after inoculation. The pathogen was successfully reisolated from the symptomatic tissue and control plants remained symptomless.

Botrytis cinerea is difficult to control because it has more than 200 hosts, different sources of inoculum, a variety of modes of attack and long period of survival as sclerotia (Williamson et al. 2007). To our knowledge, this is the first report of $B$. cinerea causing damping-off on $M$. cinnamomifolia seedlings in forest nursery in Brazil.

Acknowledgments The authors thank Conselho Nacional de Desenvolvimento Científico e Tecnológico - CNPq, Coordenação de Aperfeiçoamento de Pessoal de Nível Superior - CAPES and Fundacão de Amparo a Pesquisa do Estado de Minas Gerais - FAPEMIG for financial support.

\section{References}

Caires N, Rodrigues FA, Furtado GQ (2015) Infection process of Botrytis cinerea on eucalypt leaves. J Phytopathol 163:604611. doi:10.1111/jph. 12360

Ellis MB (1971) Dematiaceous Hyphomycetes CMI: Kew. Surrey, UK

Farr DF, Rossman AY (2016) Fungal Databases, Systematic Mycology and Microbiology Laboratory, ARS, USDA http://ntars-gringov/ fungaldatabases/ Accessed 07 July 2016

Lorenzi H. Árvores brasileiras: manual de identificação e cultivo de plantas arbóreas nativas do Brasil. Editora Plantarum, Nova Odessa, p 236

Mendes MAS, Urben AF (2016) Fungos relatados em plantas no Brasil, Laboratório de Quarentena Vegetal. Embrapa Recursos Genéticos e Biotecnologia, Brasília. http://pragawall.cenargen.embrapa. br/aiqweb/michtml/fgbanco01.asp . Accessed 07 July 2016

White TJ, Bruns T, Lee S, Taylor J (1990) Amplification and direct sequencing of fungal ribosomal RNA genes for phylogenetics. In: PCR protocols: a guide to methods and applications. Ed. by Innis MA, Gelfand DH, Sninsky JJ, White TJ. San Diego: Academic Press. pp. 315-322.

Williamson B, Tudzynski B, Tudzynski P, Van Kan JAL (2007) Botrytis cinerea: the cause of grey mould disease. Mol Plant Pathol 8:561580. doi:10.1111/j.1364-3703.2007.00417.x 